
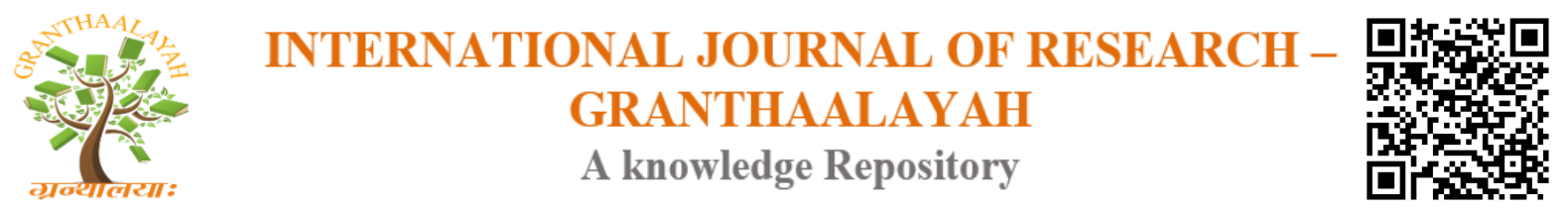

Social

\title{
AN ANALYSIS ON THE SELF-INITIATION SELF REPAIR STRATEGIES OF THE THIRD SEMESTER STUDENTS OF ENGLISH STUDY PROGRAM IN THE ORAL INTERACTION WITH THEIR LECTURER AT WIDYA MANDIRA CATHOLIC UNIVERSITY KUPANG IN ACADEMIC
}

\author{
Maria Wihelmina Wisrance ${ }^{* 1}$ \\ ${ }^{* 1}$ Post Graduate English Education Study Program, Nusa Cendana University, Kupang, \\ Indonesia
}

\begin{abstract}
This article studies self-initiation self-repair employed by the third semester students of English study program of Widya Mandira catholic university Kupang on speaking class, aims at finding out whether or not the third semester students of English study program do the self-repair initiation toward the trouble source they produce on the interaction they are engaged. The main purposes are to discover the types of trouble source that trigger the students' self-initiation selfrepair, the self-repair strategies performed by the students on the interaction with their lecturer, and identify the way how the students produce the self-initiation self-repair. The qualitative method and CA approach were employed as a theoretical framework. The results indicated that; types of trouble sources that trigger students' self-initiation self-repair in the interaction with their lecturer on speaking class were vocabulary, pronunciation, and grammar. The self-initiation self-repair strategies performed by the students in their interaction with their lecturer on the speaking class were replacement, partial repetition of pronunciation, completion, correction, repetition by modifying intonation, modification, and rearranging. The self-initiation self-repair strategies are done in six ways namely repeating, replacing, modifying, correcting, completing, and rearranging.
\end{abstract}

Keywords: Analysis, Classroom Interaction; Self-initiation Self Repair; Trouble Source.

Cite This Article: Maria Wihelmina Wisrance. (2017). "AN ANALYSIS ON THE SELFINITIATION SELF REPAIR STRATEGIES OF THE THIRD SEMESTER STUDENTS OF ENGLISH STUDY PROGRAM IN THE ORAL INTERACTION WITH THEIR LECTURER AT WIDYA MANDIRA CATHOLIC UNIVERSITY KUPANG IN ACADEMIC." International Journal of Research - Granthaalayah, 5(12), 311-317. https://doi.org/10.29121/granthaalayah.v5.i12.2017.463. 


\section{Introduction}

Human beings as social creatures are born to interact with each other in their everyday life. These interactions are crucial to fulfill their need as well as resolve or ease their problem. Practically, people will create conversation when they interact to each other. In interacting each other, people use language. Language is used to interact direct and indirectly. The oral form of language is used when people interact directly or in the other way around, people use language in written form when they want to convey a message indirectly (Djahimo, 2016). Conversations which formed by the interaction are worth analyzing for they have a lot of interesting linguistics phenomena during their occurrences such as interruption and repair.

In this globalization era, English is used worldwide. It is used in many countries either as first or second language. In Indonesia, English is accepted as the first foreign language. It is taught as a compulsory subject from junior high school (SMP), Senior high school (SMA), to University.

In learning English as a foreign language, there are many difficulties faced by students. They need their messages or information to be understood by the other students. When they speak they need to be able to say what they really want to say. This means that their grammar, vocabulary, and the pronunciation should be at least adequate for the purpose. Hence, the students need to be provided with a good knowledge of repair to improve their spoken interaction skill in case of communication breakdowns or in case of getting mutual understanding from the conversation they are engaged.

Repair as the nature activity occurs in oral exchanges refers to the process available to speakers through which they can deal with problem which arise in talk (Liddicoat, 2007:182). It reveals that the speaker (s) is trying to solve language problem which might affect normal flow of communication (Van Lier, 1988). An organization of repair operates in conversation is addressed to recurrent problems in speaking, hearing, and understanding Schegloff, E. A., Jefferson, G., \& Sacks, H (1977). Therefore, conversation could not be conversation if universal interactional resources for making meaning as repair do not exist is stressed Pica (1987). Repair, then is seen as engine that drives inter language development forward. The ideas above show how important repair are in a conversation. If the speakers in a conversation could not understand each other, repair becomes an important strategy to be employed by the speakers to get mutual understanding of their conversation.

Some observations done by the researcher show that, repair strategies especially self-initiation self repair strategies is rarely employed by the students when they produce trouble-source in their turn of speaking in the conversation they are engaged in the classroom. As the consequence, students still go with errors they produce. It is argued that classroom repair as the treatment of trouble occurring in classroom discourse Seedhouse (2004). The trouble could be anything which the participants of classroom conversation judge is impeding their communication. Although Sato and Takatsuka (2016) stated that errors in classroom are natural and happen as a part of learning, classroom repair is a vital mechanism in classroom for learners and teachers to understand how breakdowns in communication and misunderstanding are repaired and how the mutual understanding are maintained. 
Based on the issue mentioned above, the researcher is triggered to conduct a study on the interaction between teacher and students in the English class, to find out whether or not there is a self initiation self repair from the students themselves toward the trouble sources they produce in the classroom interaction. This study is carried out under the title, "An Analysis on the Third Semester Students of English Study Program's Self-Initiated Self Repair Strategies in the Oral Interaction with Their Lecturer at Widya Mandira Catholic University Kupang in Academic Year 2017/2018".

\section{Materials and Methods}

This research is qualitative research and conversation analysis was the employed approach in analyzing the data. This study was conducted at Widya Mandira catholic university, Penfui, Kupang, Indonesia.

The subjects of this study were the 43 third semester students of English study program of Widya Mandira catholic university, Kupang (13 males and 30 females). The main source of data for this study was taken from the recorded interactions between students and a lecturer on speaking class. There were some procedures followed by the researcher in conducting this study namely; data gathering which was done by recording the whole classroom interaction of the third semester students for four times meeting. After gathered the data, the researcher continued with the next step, data transcription. In this step, the recorded data were replayed and transcribed using the transcription convention proposed by Schegloff in 2007. When all recorded data being transcribed, the researcher came to sclassify the data to be based on the types of trouble sources and the repair strategies. Soon as the data were classified, the researcher then analyzed it to find out the types of trouble sources, the repair strategies, and the way the students employed the repair strategies. Finally, the data were discussed to be then reported as the result of the study.

\section{Results and Discussions}

From the repair strategies proposed by Schegloff, et al (1977), zhang (1998), Tang (2011), and Reisa (2014), it was found six patterns of self-initiation self repair strategies plus one other pattern the researcher proposed in students lecturer interaction, namely replacement (24), partial repetition of trouble source in pronunciation (12), completion (4), correction (2), repetition by modifying intonation (1), and modification (1), and rearranging (2). These repair strategies patterns were employed as the result of the trouble sources in vocabulary, pronunciation, and grammar. The result indicated that there were six ways of producing self-initiation self-repair strategies as repeating, replacing, modifying, correcting, completing, and rearranging. The examples are arranged bellow:

\subsection{Partial Repetition of Trouble Source: Pronunciation}

A partial repetition means an initiation of repair done by repeating some part of someone utterance considered as the trouble source. The repetition in this case happened as the problem in pronunciation. Notice the following example: 


\section{Extract 10}

S10 Kupang is a beautiful city with many friendly people. Many tourism came to Kupang because Kupang is a nice kultur uh nice /kıltfə(r)/ especially Kupang has uh beautiful traditional dancer.

The above illustration showed that the S10 produced the wrong pronunciation of the word culture. He pronounces kultur instead of $k \Lambda l t f \partial(r)$. Aware of wrongly pronounce the word, S10 directly repeating the the word which become the trouble source kultur into $\underline{k A l t} \int \partial(r)$.

\subsection{Repetition by Modifying Intonation}

A repetition by modifying intonation is an initiation of repair done by repeating some part of someone utterance and then modifies its intonation.

\section{Extract 22}

S11 : Ok. The next topic is Culinary. In Soe, there are many traditional food? In Soe there are many traditional food. The first food is: Jagung Bose ((smiling))

The extract 22 above shows that there is a trouble source produced by student 11 . In the first chance, she utters the sentence in Soe there are many traditional food? with high intonation. Being realizes that there is no more clause to be continued after the previous clause she mentions before, the student directly self-initiates the trouble source by repeating the same clause, and modifying its intonation through putting the full stop at the end to make it become a sentence In Soe there are many traditional food. The first food is.....

\subsection{Replacement}

In repair completion, replacement pattern is often used to replace word(s) with another that is considered more appropriate or precise by the repair completer. The example of this repair pattern can be seen in the following data:

\section{Extract 23}

S9 : There local dances that kultur in Kupang, those are Tebe and Dansa uh dance: but people in Kupang always to call it dance, dansa.

Student 9 on the example above is talking about the traditional dances of Kupang. He mentions that there are two kinds of traditional dance in Kupang, they are Tebe and Dansa. The student finds it difficult to determine which word is suitable to be used dance or Dansa, thus in his first sentence he says "...Tebe and Dansa uh Dance". As a matter of fact, a kind of dance which is usually identical with any parties in Kupang is called Dansa. Later, the student finds a more suitable term for the term he meant, i.e. Dansa. Altough in the next sentence he is still confuse of which term should be used, but finally he says "but people in Kupang always to call it dance, dansa" that puts the word Dansa at the end of the sentence, indicates that Dansa is the term he meant to be explained in his speech. The trouble is on the word or term to be used. A similar case occurs in the following datum. 


\subsection{Modification}

The main function of this pattern is to improve the quality of speech in order to make the utterance becomes more informative. The modification pattern is done by inserting extra constituent in the original utterance. The extra constituent may include additional information, like numbers, adverb of time or place and adjectives, or just simply adding conjunction to form any meaning the speaker intent to say. Notice the following datum:

\section{Extract 47}

S1 : Uh Kupang uh have uh femous, many of /feImos/ places uh like uh Lasiana beach. In Lasiana beach is fery beautiful (place) and many of tourism go there and like uh Lasiana beach. And.

The above example is the S1 speech about Lasiana beach. The student starts the speech by telling that Kupang has famous places. However in her utterance, the S1 forgets to attach the word many to emphasize a number of famous places in Kupang. Therefore, she modifies her utterance by inserting many after the word have. In another case, even the speaker produces the trouble in using have for Kupang, but she doesn't notice it.

\subsection{Correction}

The function of this repair pattern is to adjust the phonemic or morphemic. When correction is implemented, the interpretation is not targeted for a change:

\section{Extract 48}

S13 : And, seken, Laipopu waterfal. It is the picture of Laipopu waterfall ((showing the picture)). From waikabubak to this waterfall, you only need at least one hour but the trip will be paid with the beautifull, with the beauty of the waterfall.

Compound noun should be composed of two noun constituents; however, the speaker misapplies an adjective to be the first element of the noun phrase. Thus, the speaker produces a selfinitiation repair by correcting the adjective beautiful and putting the noun beauty for a correct construction.

\subsection{Completion}

Completion is a pattern that enables participants in an ongoing conversation to complete an incomplete utterance. The incomplete utterance usually happens either for the speaker is no longer able to express his thought verbally or the speaker is gaining time to think about the most appropriate word(s) to say. The examples are showed below.

\section{Extract 50}

Indonesia and there, there is uh a leader uh a leader of Kupang is name, 
The trouble source from the speech above is that the speaker find it difficult to get next word to continue the sentence. After a while of thinking by producing Uh... she finds a word yet mispronounced it kontri. What she means is country.

\subsection{Other: Rearranging}

Besides patterns of repair proposed by Zhang (1998), Tang (2011), and Rheisa (2014), the researcher found one other pattern in the repair investigation of the third semester students' selfinitiation patterns on the interaction with their lecturer namely rearranging. It reveals the speaker rearranges the unproper order statement into a good order.

\section{Extract 56}

S22 : Ok, thanks for the chance given to me ((smiling)) given to us. Now we are going to explain about city Kefa, Kefa city. The city of Kefamenanu is the kapital of TTU district.

The student 22 on the example above is promoting Kefa. As she begins the presentation, she says ".....we are going to explain about city Kefa". City Kefa is not a good English system of language. It is Indonesian language system, as we say Kota Jakarta, Kota Bandung, Kota Surabaya, and so on. In English system, we say Jakarta city or New York city, but not city New York. Realizing this trouble source, the student directly self-initiates and employs a repair pattern by rearranging the order as Kefa city.

\section{Conclusions and Recommendations}

After analyzing and discussing the interaction between the third semester students of English study program of Widya Mandira catholic university and based on research findings and discussion, the conclusions of this research could be drawn as; first, types of trouble sources that trigger students self-initiated self-repair in the interaction with their lecturer on speaking class are vocabulary, pronunciation, and grammar; second, the self-initiated self-repair strategies performed by the students in their interaction with their lecturer on the speaking class are replacement, partial repetition of pronunciation, completion, correction, repetition by modifying intonation, modification, and rearranging; third, the self-initiation self-repair strategies are done in six ways as repeating, replacing, modifying, correcting, completing, and rearranging.

\section{Acknowledgements}

Praise to the almighty God and virgin Marry for the great blessing through which the researcher can finish this research. So much thanks also for those who have been so far providing supports, guidance, and advice so that this research can be finished. Special thanks for my beloved parents; Gerardus M. Vincentius and Hortensia Rasmina, beloved sister Vindy Bella, beloved engage Handrianus Welan, for my nice supervisors Mr. Bire and Ms. Santri Djahimo, examiners Mr. Tans and Mr. Haan, and also some friends Ina Salem, Jenny Bay, and Yandres Lao. 


\section{Appendices}

In transcribing the recorded data, the researcher used the trancription key proposed by Schegloff (2007) in Wong and Waring (2010:15). The researcher also used some keys as:

L : Lecturer

SS : All students

S1-S43: Particular students

\section{References}

[1] Djahimo, Happy Rosita. (2016). A Study on the Form of Code-Mixing Used by Kristi Jo in Her Promises' Novel. Jurnal Ilmu Pendidikan Bahasa, Vol. 03, No. 03, ISSN: 2303-2820. Kupang: Program Pendidikan Bahasa Inggris Pascasarjana Undana.

[2] Liddicoat, Anthony J. (2007). An Introduction to Conversation Analysis. Great Britain: Athenaeum Press Ltd.

[3] Pica, T. (1987). The Impact of Interaction on Comprehension. TESOL Quarterly, 21, 737-759.

[4] Sato, Rintaro \& Takatsuka, Shigenobu (2016). The Occurrence and the Success Rate of SelfInitiated Self-Repair. The Electronic Journal for English as a Second Language (Vol 2)

[5] Schegloff, E. A., Jefferson, G., \& Sacks, H. (1977). The preference for self-correction in the organization of repair in conversation. Language, 53, 361-382.

[6] Reisa, Nadia Sivanya. (2014). A Conversation Analysis of Repair in the Oprah Winfrey Show: A Special Episode With Michael Jackson. Yogyakarta: Universitas Negeri Yogyakarta. (Unpublished Thesis)

[7] Van Lier, L. 1988. The Classroom and the Language Learner. London: Longman

[8] Waring, Hansun \& Jean Wong. 2010. Conversation Analysis and Second Language Pedagogy: A Guide for ESL/EFL Teachers. New York: Routledge

[9] Woofit, Robin. 2005. Conversation Analysis and Discourse Analysis: A Comparative and Critical Introduction: London: Sage

\footnotetext{
*Corresponding author.

E-mail address: anchewelan@ gmail.com
} 